\title{
STREAM FLOW AND LAND USE LAND COVER CHANGE IN FINCHAA HYDROPOWER, BLUE NILE BASIN, ETHIOPIA
}

\author{
MEGERSA KEBEDE, ANKIT CHAKRAVARTI \& TAMENE ADUGNA
}

Faculty of Civil and Environmental Engineering, Jimma Institute of

Technology, JIT, Jimma University Jimma, Oromia, Ethiopia

\begin{abstract}
In all over the world, land use land cover changes (LULCC) effect on the water storage structures is important for proper management of water resources and its uses. The effects of LULCC and improper management systems have played a significant role for sediment transport movement, regulation and life expectancy of the reservoir. For the analysis of LULCC in Finchaa watershed the geographic information system (GIS) version based SWAT has been used to evaluate sensitivities and patterns of LULCC. To predict stream flow because of LULCC calibration and validation of the soil and water assessment tool were applied using the compatible version of SWAT CUP against stream flow for Finchaa hydropower reservoir were taken to estimate model performance on monthly basis. LULCC involve all the parameter which are responsible to decrease the proper regulation and performance in ecosystem. To predict stream flow changes the analysis were performed on surface runoff, sediment yield and flow of ground water. It was found that the SWAT model predict stream flow due to LULCC reasonably well having $R^{2}$ values of 0.71 \& 0.74 and Nash-Sutcliffe efficiency were found to be $0.68 \& 0.72$ for calibration and validation of the model resulting the best model to predict hydrological process of the basin or catchment.

KEYWORDS: Land Use Land Cover Change, Sensitivity Analysis \& SWAT CUP
\end{abstract}

Received: Jul 29, 2017; Accepted: Aug 18, 2017; Published: Aug 28, 2017; Paper Id.: IJCSEIERDOCT20171

\section{INTRODUCTION}

Land and water are the two most precious and fundamental resources essentially required not only for nourishment of life but also for the economic and social development of the country. The main cause of LULC changes due to hydrological events such as overland flow runoff, infiltration, evaporation, percolation and stream flow (Li, et al., 2007, chakravarti et al., 2014, 2015) and also due to human induced factors such as deforestation, urbanization, land grazing, wood and fuel utilization. Africa is experiencing rapid and substantial social, economic, climatic and environmental change. Ethiopia experiences persistent land, water and environmental degradation due to localized and global climatic variances. The dynamics of land use is one of the major environmental problems in Ethiopia (Berhan, 2010). Man- made reservoirs usually satisfy multiple objectives including flood control, irrigation, hydropower generation, water supply, boating, fishing and recreation. Blue Nile Basin is the bigger area in Ethiopia having big population density, land degradation and mostly required on agricultural economy (Tsegaye, 2006). The main factors of erosion and stream flow problems are land use changes which have been induced by Finchaa reservoir. The main purpose of this study is to calibrate and validate the hydrologic SWAT model based on a stream flow data of hydropower reservoir, using Geographic Information System (GIS) based version of the model to use as efficiency as compared to other model to access the available resources such as LULCC, 
deforestation and change of watershed management. With respect to available water resources, any LULCC may affect the hydrological cycle and its water balance terms. Increase in the intensity of rainfall has a significant impact on soil erosion rates and increase the rates of runoff to the reservoir. The rain storm intensity cause significant erosion and sediment movement resulting the operation and maintenance cost increase and reducing life of hydraulic structures (Tamene, et al., 2005).

Finchaa hydropower reservoir is a highland area with a severe soil erosion problem that drains to the Blue Nile River, which may result in reducing the capacity of water storage in the reservoir. The development of Finchaa dam and Finchaa Sugar Estate caused the changes of land use and the rate of environmental degradation downstream of Finchaa watershed in general. Therefore, to address the above situation, watershed management is one of the most important approaches, which helps to reduce land degradation, increase vegetation cover, and increases the productivity of the watershed area. A suitable examination of the runoff yield of the catchment is essential for management of sediment yield and operation of water resource.

\section{STUDY AREA DESCRIPTION}

The study area is located in Horro Guduru Wollega zone, East Wollega, Oromia regional state, western Ethiopia between $9^{\circ} 46^{\prime} 45^{\prime \prime}-9^{\circ} 10^{\prime} 30^{\prime \prime}$ North latitude and $37^{\circ} 28^{\prime} 30^{\prime \prime}-37^{\circ} 03^{\prime} 00^{\prime \prime}$ (Figure 1). Finchaa sub-basin is a part of Blue-Nile basin. The sub-basin has an area of $4089 \mathrm{~km}^{2}$. Finchaa dam was constructed in 1973 for the development of economic growth in the country and it was expanded by diverting Amerti river flows into the Finchaa reservoir, by constructing a $20 \mathrm{~m}$ high earth and rock fill dam and $1.57 \mathrm{~km}$ long diversion tunnel, thereby diverting Amerti river to reservoir in 1987. At the time the dam was the largest hydro-electric Projet in the country. The Finchaa hydropower dam which has a 340 meter crest length and height above lowest foundation level is 20 meter.

\section{MATERIALS AND METHODS}

The Main Materials used for Input Data Preparation, Analysis Were

- Arc SWAT, SWAT-CUP, PCP STAT, Dew02.exe, Microsoft Excel, DEM, Meteorological, Hydrological map and data

The methods used here in this research work involved validation, calibration, sensitivity and uncertainty analysis. SUFI-2 used as calibration and uncertainty analysis algorithms were used.

The Methodology of this Work has the Following Components

- Collection of data, processing, input model, sensitivity test, calibration \& validation of model, Model result analysis.

Geographical Information System-GIS based version of soil and water Assessment Tool-SWAT were applied to analyze overall methodology. Finally, calibration, validation and evaluation by appropriate systems to check the model performance with observed data.

\subsection{SWAT Model Description}

SWAT has already been validated in the regions of the world for a variety of applications in hydrologic and was developed for the reason of simulation estimate the management of land practices, sediment movement in large of the 
watersheds by changing soils, land use and agricultural conditions over extended time periods (Neitsch, et al., 2005).

SWAT can be used to analyze small or large catchments by discrediting them into sub-basins, which are then further sub-divided for modeling purpose. The catchment is divided into a number of sub-basins which will be divided into hydrological response units (HRUs) each having homogeneous land use, soil types, and management and slope characteristics. The water balance in hydrological response units is calculated on the bases of day by day precipitation, evapotranspiration, overland flow, infiltration and subsurface and groundwater return flow.

$$
\mathrm{SW}_{\mathrm{t}}=\mathrm{SW}_{\mathrm{o}}+\sum_{\mathrm{i}=1}^{\mathrm{t}}\left(\mathrm{R}_{\mathrm{day}}-\mathrm{Q}_{\mathrm{Surf}}-\mathrm{Ea}-\mathrm{w}_{\text {seep }}-\mathrm{Q}_{\mathrm{gw}}\right)
$$

Where $S W_{t}=$ Final soil water content in $\mathrm{mm}, S W_{o}=$ Initial water content in $\mathrm{mm}, R_{\text {day }}=$ Precipitation on day i in $\mathrm{mm}, Q_{\text {Surf }}=$ Surface runoff on day i in $\mathrm{mm}, E a=$ evapotranspiration on day $\mathrm{i}$ in $\mathrm{mm}, w_{\text {seep }}=$ Water entering the vadose zone from the soil profile on day i in $\mathrm{mm}, Q_{g w}=$ Return flow on day i in $\mathrm{mm}, t=$ Time in days.

\subsubsection{Surface Runoff}

SWAT uses two methods for calculating surface runoff namely, modified Soil Conservation Service curve number technique (USDA-SCS, 1972)and for infiltration method Green \& Ampt were used (Green and Ampt, 1911). The SCS techniques were applied in the present investigation, which is a function of permeability of soil, land use and AMC (antecedent moisture content). In SCS technique, curve number changes non-linearly with soil moisture content. Green \& Ampt technique requires sub-daily precipitation data and estimate infiltration as a function of the wetting front metric potential and effective hydraulic conductivity. The SCS curve number equation is given by the following equation:

$$
\mathrm{Q}_{\text {surf }}=\frac{\left(\mathrm{R}_{\mathrm{day}}-\mathrm{Ia}\right)^{2}}{\left(\mathrm{R}_{\mathrm{day}}-\mathrm{Ia}+\mathrm{s}\right)}
$$

Where $Q_{\text {surf }}=$ Rainfall excess in $\mathrm{mm}_{2} \mathrm{O}, \mathrm{R}_{\text {day }}=$ Depth of rainfall in day in $\mathrm{mm}_{2} \mathrm{O}$,

Ia = Initial abstractions, infiltration \& interception in $\mathrm{mm}_{2} \mathrm{O}, \mathrm{S}=$ Retention parameter in $\mathrm{mm}_{2} \mathrm{O}$.

The retention variable changes spatially because of variation in soils type, land cover, slope and soil water content. The equations to define the retention parameter are shown by the following equation:

$$
S=25.4\left(\frac{100}{C N}-10\right)
$$

Where: $\mathrm{CN}=$ Curve number in days. Ia, can be written as $0.2 \mathrm{~S}$. So that the equation 3.2 can be converted into the following equation:

$$
\text { Qsurf }=\frac{\left(\mathrm{R}_{\mathrm{day}}-0.2 \mathrm{~S}\right)^{2}}{\left(\mathrm{R}_{\mathrm{day}}+0.8 \mathrm{~S}\right)}
$$

The overland flow comes when $\mathrm{R}_{\text {day }}$ greater then Ia. The rate of peak overland flow is the maximum overland flow (runoff) rate that occurs with a given rainfall event. The peak overland flow rate is an indicator to predict sediment loss. SWAT model estimate the peak runoff rate with a modified rational method (Neitsch, et al., 2005) which can be express by the following formulas:

$$
\mathrm{q}_{\text {peak }}=\frac{\text { C.i.A }}{3.6}
$$


Where: $\mathrm{q}_{\text {peak }}=$ Peak rate of runoff in $\mathrm{m}^{3} / \mathrm{s}, \mathrm{C}=$ Coefficient of runoff, $\mathrm{I}=$ Intensity of rainfall in $\mathrm{mm} / \mathrm{hr}, \mathrm{A}=\mathrm{basin}$ area in $\mathrm{km}^{2}$.

\subsubsection{Sediment Component}

SWAT model determines the amount of sediment component in terms of the surface erosion and sediment yield under every hydrologic event unit with modified universal soil loss equation. The quantity of stream sediment routing is based on the high amount of sediment which can be transported from a reach segment, and is a function of peak channel velocity (Neitsch, et al., 2011). The modified universal soil loss equation can be express as follows:

$$
\text { Sed }=11.8\left(Q_{\text {surf }} \cdot q_{p e a k} \cdot A_{h r u}\right)^{0.56} \cdot K_{U S L E} \cdot C_{U S L E} \cdot P_{U S L E} \cdot L S_{U S L E} \cdot C_{F R G}
$$

Where: Sed $=$ Sediment yield on a given day in tons, $Q_{\text {surf }}=$ Surface runoff amount in $\mathrm{mm}$ water/ha, $q_{\text {peak }}=$ Rate of peak in $\mathrm{m}^{3} / \mathrm{s}, \mathrm{A}_{\mathrm{hru}}=$ Basin area in ha, $\mathrm{K}_{\mathrm{USLE}}=$ Erodibility Value.

The deposition and degradation are the two processes of sediment transport in the channel system in the reach. Degradation observes when soil concentration is lesser than quantity of soil which can be moved from a reach segment and deposition observes when soil concentration is high than the maximum amount. The sediment amount in the reach can be described by the following equations:

$$
\operatorname{sed}_{c h}=\operatorname{sed}_{c h, i}-\operatorname{sed}_{d e p}+\operatorname{sed}_{d e g}
$$

Where $\operatorname{sed}_{\mathrm{ch}}=$ Quantity of suspended particles in reach in metric tons/day, $\operatorname{sed}_{\mathrm{ch}}, \mathrm{i}=$ Quantity of suspended particles in reach at the beginning of the time in metric tons/day, $\operatorname{sed}_{\text {dep }}=$ Quantity of deposited particles in the reach in metric tons/day and $\operatorname{sed}_{\mathrm{deg}}=$ Quantity of sediment re-entrained in the reach in metric tons/day.

The Quantity of transported particles out of the reach can be estimated by the following equations:

$$
\operatorname{sed}_{\text {out }}=\operatorname{sed}_{c h} * \operatorname{sed}_{\text {dep }} \frac{V_{\text {out }}}{V_{c h}}
$$

Where $\operatorname{sed}_{\text {out }}=$ Quantity sediment moved out of the reach in metric tons/day, Sed $\mathrm{ch}_{\mathrm{c}}=$ Quantity of suspended particles in the reach in metric tons/day, $V_{\text {out }}=$ Quantity outflow during time step in $\mathrm{m}^{3} / \mathrm{s}$, and $\mathrm{V}_{\mathrm{ch}}=$ Quantity of water in the reach in $\mathrm{m}^{3}$.

\subsubsection{Estimation of Potential Evapotranspiration}

The parameter of evapotranspiration is estimated by Penman-Monteith equation which can able to estimate all the climatic parameter required by the SWAT model. The equation to estimate the above parameter is given by the following equations:

$$
E T_{0}=\frac{0.408 \Delta\left(R_{n}-G\right)+\gamma \frac{900}{T+273} U_{2}\left(e_{S}-e_{a}\right)}{\Delta+\gamma\left(1+0.34 U_{2}\right)}
$$

Where $\mathrm{ET}_{\mathrm{o}}=$ Amount of evapotranspiration $\left(\frac{m m}{d a y}\right), \mathrm{R}_{\mathrm{n}}=$ Net radiation at the crop surface $\left(\frac{M J}{m^{2} d a y}\right), \mathrm{G}=$ Soil heat flux density $\left(\frac{M J}{m^{2} \text { day }}\right), \mathrm{T}=$ Mean daily air temperature at $2 \mathrm{~m}$ height $\left({ }^{0} C\right), \mathrm{U}_{2}=$ Wind speed at $2 \mathrm{~m}$ height $\left(\frac{m}{s}\right)$, $\mathrm{e}_{\mathrm{s}}=$ Saturation vapor pressure in $\mathrm{KPa}, \mathrm{e}_{\mathrm{a}}=$ Actual vapor pressure $\mathrm{KPa},\left(\mathrm{e}_{\mathrm{s}}-\mathrm{e}_{\mathrm{a}}\right)=$ Saturation vapor pressure deficit $\mathrm{KPa}, \Delta=$ Slope vapor pressure curve $\left(\frac{K P a}{0_{C}}\right), \gamma=$ Psychometrics constant $\left(\frac{K P a}{0_{C}}\right)$ 


\subsection{Data Input and Their Sources}

SWAT model is highly data concentrated model that requires specific information of the basin. The input data's required for this study were Digital Elevation model (DEM), land use and land cover map, soil map and data, stream flow data, and weather data. These data were collected from different sources.

A Digital Elevation Model of $30 \mathrm{~m}$ by $30 \mathrm{~m}$, in the Grid format and projected was used in this study and the original DEM in geographic coordinate system was obtained from Ethiopian Ministry of water, Irrigation and Energy bureau GIS Department.

The LULC data for this study area was obtained from Ethiopian Ministry of water, Irrigation and Energy bureau GIS Department.

The sediment input data required by SWAT model to calculate stream flow includes the relevant hydraulic conductivity properties such as bulk density, hydraulic conductivity available water capacity of sediment. The parameters of sediment data were obtained from Ethiopian Ministry of water, Irrigation and Energy bureau GIS Department.

Daily stream flow was obtained from Ethiopian Ministry of water, Irrigation and Energy bureau hydrology Department and the available weather data for the selected stations were obtained from Ethiopian National Meteorological Service Agency. The average monthly minimum and maximum temperature patterns of different stations (1985-2014) (Fig. 2 and 3 )

\subsection{Input Data Preparation, Processing and Analysis}

After the data was collected, an analysis of all the collected data was made. One of the problems in hydrology especially in developing countries is hydrological data both in quantity (length of record) and quality (standard of scientific approach). The output of any research depends highly on data input. The acquired data were checked for any outliers and missing values. The missing meteorological and stream flow data were filled using linear regression method.

\subsection{SWAT-CUP}

SWAT-CUP is an interface that was developed for SWAT. SWAT-CUP is designed to integrate various sensitivity analysis, calibration, validation and uncertainty programs for SWAT using different interface. The function of interface is to provide a link between the input and output of a calibration program and the model. Using this generic interface, any calibration, validation, uncertainty or sensitivity program can easily be linked to SWAT.

\subsection{Model Calibration and Validation}

The calibration is an intensive process used to make the suitable variables in modeling and an iterative process that compares simulated and observed data of interest (typically stream flow data) through parameter evaluation. The degree of accuracy of parameter estimation was assessed by applying the model to different data set that was not used for calibration.

\subsection{Model Efficiency}

The performance of the model to simulate the stream flow during the calibration and validation periods has been evaluated, based on the computed results of the indicators and the suggested model performance rating standards. The methods for goodness of fit measures the model predictions were applied for calibration and validation process, these 
model performance measures the variation in the measured data that is replicated in the simulated model results are coefficient of regression $\left(\mathrm{R}^{2}\right)$ and the Nash-Sutcliffe efficiency (NSE). $\mathrm{R}^{2}$ ranges from 0.0 to 1.0 with higher values indicating better agreement (Legates and McCabe, 1999) and the value of NS ranges from minus infinity to 1.0, with higher values indicating better agreement (Legates and McCabe, 1999).

$\mathrm{R}^{2}$ is calculated by the following equation:

$$
\mathrm{R}^{2}=\frac{\left[\sum_{\mathrm{i}=1}^{\mathrm{n}}(\mathrm{q} s \mathrm{i}-\overline{\mathrm{q}} \mathrm{s})(\mathrm{qoi}-\overline{\mathrm{q}} \mathrm{o})\right]^{2}}{\sum_{\mathrm{i}=1}^{\mathrm{n}}(\mathrm{q} s \mathrm{i}-\overline{\mathrm{q}} \mathrm{s})^{2} \sum_{\mathrm{i}=1}^{\mathrm{n}}(\mathrm{qoi}-\overline{\mathrm{q}} \mathrm{o})^{2}}
$$

Where: qsi is simulated stream flow in $\mathrm{m}^{3} / \mathrm{s}$,qoi is observed stream flow in $\mathrm{m}^{3} / \mathrm{s}$, $\overline{\mathrm{q}} \mathrm{sis}$ the mean of the simulated value, $\overline{\mathrm{q}}$ ois the mean of the observed value.

The Nash-Sutcliffe simulation of the model efficiency indicates the degree of fitness of the observed and simulated plots. It is calculated as follows with the same variables defined above:

$$
\mathrm{NS}=1-\frac{\sum_{\mathrm{i}=1}^{\mathrm{n}}(\mathrm{qoi}-\mathrm{qsi})^{2}}{\sum_{\mathrm{i}=1}^{\mathrm{n}}(\mathrm{qoi}-\overline{\mathrm{q} o})^{2}}
$$

\subsection{Model Setup}

The SWAT model setup were concerned integrating the necessary input data's with the model such as DEM, watershed delineation, land cover and land use map, sediment description and their property. The basin delineation procedure contains 5 importent steps, DEM, definition of stream, inlet outlet, basin outlets selection and calculation of sub basin variables. SWAT model predict area of hydrologic cycle for every HRU and routes to predict total loadings of the catchment. For this study, 20\% land use threshold, 20\% soil and 10\% for slope was used. After land use/ soils/slope definition and HRU definition was done a shape file called 'Full HRUs' were created. As per the final report from the model the basin was divided into 27 sub-basins which were further divided into 339 hydrologic response units.

The shape file of the prepared land-use land cover was given as input for the model data of the SWAT to describe the HRU of the watershed. Consequently, the impact of each type of LULC was considered in this model to compute stream flow in the basin. To integrate the soil map with SWAT model, manually define was used. The model uses slope for the development of HRU in addition to LULC and sediment input variables. Arc SWAT allows the integration of land slope up to 5 classes when defining hydrologic response units. Table 1 shows the slope classes of the Finchaa watershed.

\section{RESULTS AND DISCUSSIONS}

\subsection{Sensitivity Analysis}

It is important to identify sensitive parameters for a model before applying SUFI-2 for calibration to avoid problems known as over parameterization (Van Griensven, et al., 2006). To know the sensitive variables, Latin hypercube simulation one at a time (LH-OAT) technique was applied (Van Griensven, et al., 2006). Twenty seven variables were predict for model parameterization sensitivity test, only twelve of them were effective and sensitive parameters that are responsible for monthly flow simulation analysis (Table 2). It was found that the sensitive variables were responsible for the model calibration and variable changes at model iteration processes. The result obtained from sensitivity test shows that the twelve flow variables were sensitive to SWAT model which means that the hydrological event of the research area mostly dependent on the action of these variables. 


\subsection{Stream Flow Calibration}

For the stream flow calibration, the comparison can be taken between the observed and computed runoff for thirteen years duration steps from 1990 to 2002 years on the monthly basis. Before running for the above time-step years, initially one year of discharge data from 1990 was used as the warming time and the rest of time was taken for the model calibration. The model is calibrated by taking 12 variables which is observed as most sensitive variables was taken for measurement of discharge and coefficient of determination $\left(\mathrm{R}^{2}\right)$ and NES is used to analyze the model efficiency for observed and computed flows on monthly basis are found to be 0.71 and 0.68 respectively. The uncertainties were measure by taking percentage of measured data bracketed referred to P-factor by 95 percent prediction uncertainty and have been calculated as 0.52. Similarly strength of the model calibration and uncertainty has been analyzed using the average thickness of 95PPU or R factor which shows the average thickness of 95PPU band divided by standard deviation of the observed data which have been computed as 0.69 .

The comparison between the computed and observed flow for the station during the calibration time was shown in figure 4 .

\subsection{Stream Flow Validation}

Calibrated parameters were validated for the period of nine years apart from that one year in was taken as warm up time. The validation shows the performance of model for computed discharge in time different from calibration.

The correlation coefficient $\mathrm{R}^{2}=0.73$ and the Nash Sutcliffe Efficiency (NSE) $=0.72$ shows a good agreement between the observed and simulated values. The representation of observed and computed stream flow for station during the validation period was shown in figure 5 .

\section{CONCLUSIONS}

The present investigation was performed to predict stream flow change son surface runoff, sediment yield and flow of ground water using SWAT model in Finchaa watershed Ethiopia. The evaluation was done in terms of the impacts of LULCC on the variation of LULC types and the variations caused depending on the LULC types on the major components of discharge including overland flow and vertical movement of water in the ground. The physically based, spatially distributed and public domain Soil and Water Assessment Tool (SWAT) was successfully used to simulate the impact of LULCCs on stream flow on the hydropower reservoir.

The model was carefully calibrated and validated for the Finchaa watershed and represent better result for the performance evaluation of the model. Therefore, SWAT can be utilized very well for hydrological simulations in the selected catchments which have capabilities to analysis of hydrological responses in the watershed. It was observed that the SWAT model predict the stream flow due to land use land cover changes reasonably well having $\mathrm{R}^{2}$ values of $0.71 \& 0.74$, and NES were found to be $0.68 \& 0.72$ for calibration and validation of the model instead of any other hydrological model or algorithm to represents the hydrological process of the catchments.

Table 1: The Slope Classes of the Finchaa Watershed

\begin{tabular}{|l|c|l|c|c|}
\hline \multirow{2}{*}{ Classes } & Slope Range & \multicolumn{2}{|c|}{ Area } \\
\cline { 3 - 5 }$(\boldsymbol{\%})$ & \multicolumn{1}{|c|}{ Land form } & Ha & \% \\
\hline Class 1 & $0-8$ & Flat or almost Flat & 218468 & 76.31 \\
\hline Class 2 & $8-30$ & Gentle Sloping, Undulating Plain & 56396 & 19.70 \\
\hline
\end{tabular}




\begin{tabular}{|l|l|l|c|c|}
\hline \multicolumn{5}{|c|}{ Table 1: Contd., } \\
\hline Class 3 & $>30$ & $\begin{array}{l}\text { Steep hills, Very steep slopes, } \\
\text { ridges, and mountains }\end{array}$ & 11436 & 3.99 \\
\hline
\end{tabular}

Table 2: Result of the sensitivity Analysis Parameters of Flow in Finchaa Watershed (Sensitivity Parameters using SUFI-2)

\begin{tabular}{|c|l|l|}
\hline & Parameters & \\
\hline NO. & \multicolumn{1}{|c|}{ Name } & \multicolumn{1}{c|}{ Description } \\
\hline 1 & CN2 & SCS runoff Curve number for moisture condition II \\
\hline 2 & ALPHA_BF & Base flow alpha factor (days) \\
\hline 3 & GW_DELAY & Ground water Delay (days) \\
\hline 4 & GWQMN & Threshold depth of water in shallow aquifer required for return flow (mm) \\
\hline 5 & GW_REVAP & Ground water 'revap' coefficient \\
\hline 6 & ESCO & Soil evaporation compensation factor \\
\hline 7 & CH_N2 & Manning's roughness coefficient for main channel \\
\hline 8 & CH_K2 & Effective hydraulic conductivity of the main channel \\
\hline 9 & ALPHA_BNK & Base flow alpha factor for bank storage \\
\hline 10 & SOL_AWC & Soil available water capacity \\
\hline 11 & SOL_K & Saturated Hydraulic conductivity \\
\hline 12 & SOL_BD & Moist bulk density \\
\hline
\end{tabular}

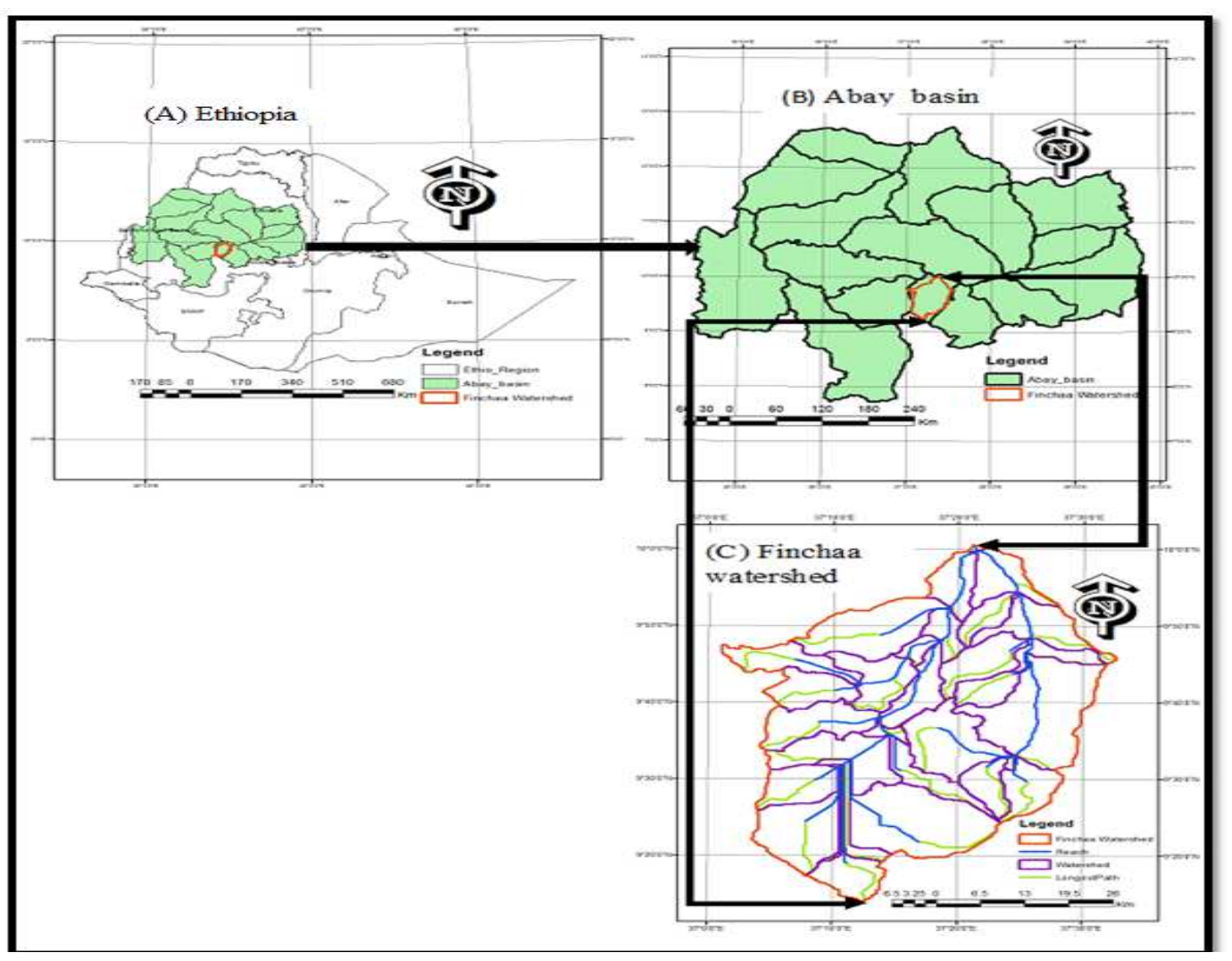

Figure 1: Location of the Study Area 


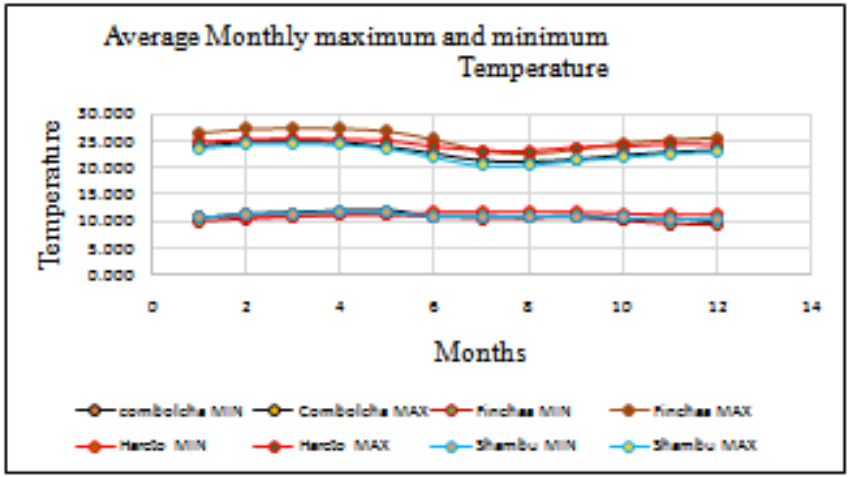

Figure 2: Average Monthly Minimum and Maximum Temperature Patterns of Different Stations (1985-2014)

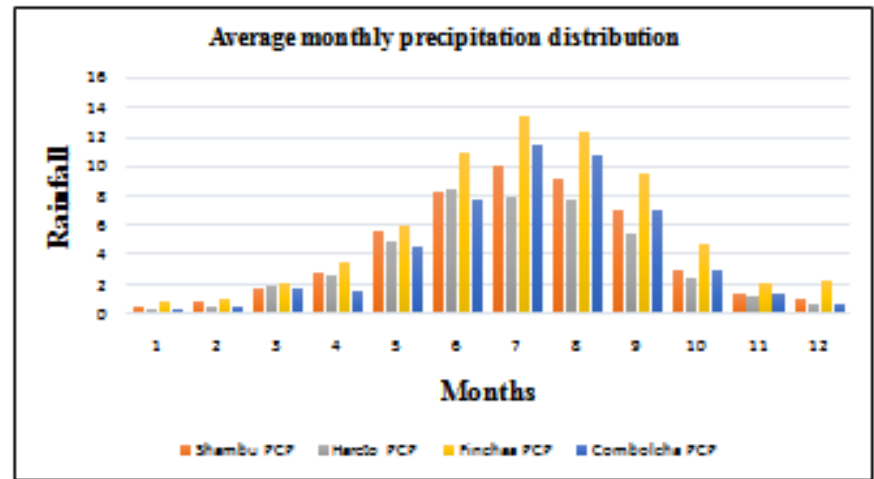

Figure 0: Average Monthly Rainfall Distributions for Different Stations (1985-2014)

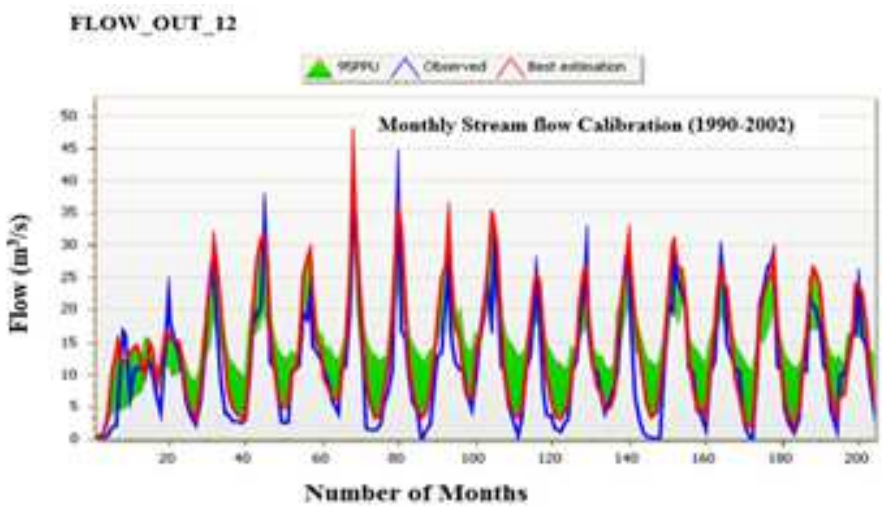

Figure 4: Calibration Result of Monthly Observed and Simulated Flows of Finchaa Watershed 
FLOW_OUT_12

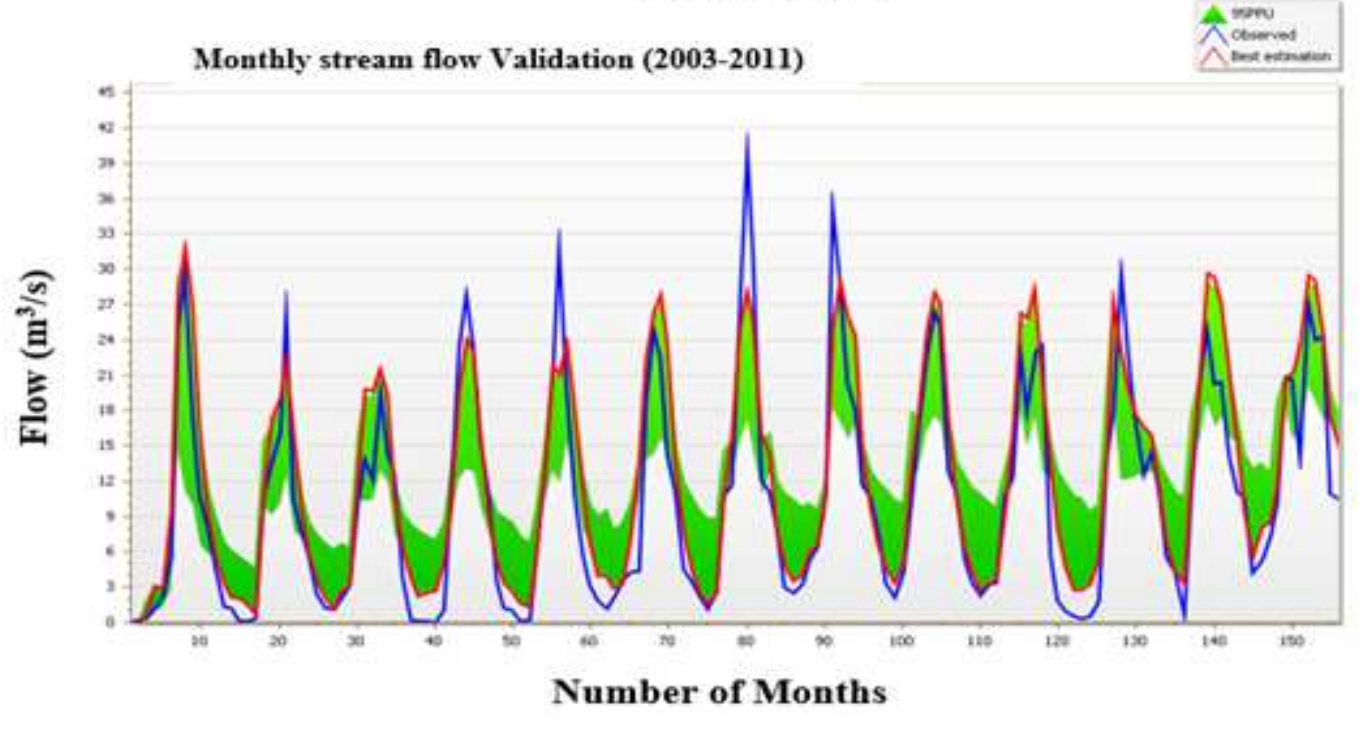

Figure 5: Validation Result of Monthly Observed and Simulated Flows of Finchaa Watershed

\section{REFERENCES}

1. Abbaspour, K., M.Vejdani, and Haghighat, S. (2007). SWAT-CUP calibration and uncertainty programs for SWAT. In proc. Int. Congress on Modelling and Simulation (MODSIM'07). 1603 -1609.

2. Ankit Chakravarti, Nitin Joshi and Himanshu Panjiar (2015) Rainfall runoff modeling using artificial neural networks. Indian Journal of Science and Technology, Vol. 8(14), pp 1-7, ISSN-0974-5645.

3. Ankit Chakravarti and M. K. Jain (2014) Experimental investigation and modeling of rainfall runoff process. Indian Journal of Science and Technology, Vol. 7(12), pp 2096-2106, ISSN - 0974-5645.

4. Assefa, K. (1994). Valuing Environmental Quality Changes in Horro-Guduru. Field Survey Report. Nekemte, Ethiopia: The Finish Forest Research Institute.

5. Berhan, G. (2010). The role of Geo-information technology for predicting and mapping of forest cover Spatio-temporal variability: Dendi district case study, Ethiopia. Journal of Sustainable Development in Africa, 12(6), 9 - 15.

6. Beven, K. J. (1989). Changing ideas in Hydrology. The Case of Physically - Based Models. Journal of Hydrology 105: 157 172. Catchments, Tanzania. Proceedings of the 3rd International SWAT conference, Zurich, 2005.

7. Bezuayehu, T. (2006). people and Dams: Environmental and soci-economic impacts of Fincha'a hydropower dam, western Ethiopia. Tropical Res. Manag.Paper. No.75. Wageningen University and Research Center, Wageningen, The Netherlands.

8. FAO. (2002). Food and Agriculture Organization of the United ations Viale delle Terme di Caracalla, 00100 Rome, Italy.

9. Goswami, M., K.M.O'Connor, Bhattari, K., and Shamseldin, A. (2005). Assessing the performance of eight real-time updating models and procedures for the Brosna River, Hydrology and the Earth system Sciences. 9(4). 394 - 411.

10. Green, W., and Ampt, G. (1911). Studies in Soil Physics,I: The Flow of Air and Water through Soils. Journal of Agricultural Sciences 4, 11 - 24.

11. Hamby, D. (1994). A review of techniques for parameter sensitivity analysis of environmental models Springer, PP. 135 - 154.

12. Hurni, H. (1989). Soil for the Future. Environmental Research for Development Cooperation, Uni Press 62, University of Berne: Berne; 42 - 46. 
13. Legates, D., and McCabe, G. J. (1999). Evaluating the use of "goodness-of-fit" measures in hydrologic and hydroclimatic model validation. Water Resour. Res. 35(1), 233 - 241.

14. Li, L., Jiang, D., Li, J., Liang, L., and Zhang, L. (2007). Advances in hydrological response to land use/land cover change. J Nat Resour 22(2), 211-224.

15. Neitsch, S. L., Arnold, J. G., Kiniry, J. R., and Williams, J. R. (2011). Soil and Water Assessment Tool - theoretical Documentation Version 2009. September 2011, Texas Water Resources Institute, Dallas, Texas, USA.

16. Neitsch, S., Arnold, J., Kiniry, J., and Williams, J. (2005). Soil and Water Assessment Tool, Theoretical documentation: Version 2005. Temple, TX. USDA Agricultural Research Service and Texas A \& M Black land Research Centre.

17. Tamene, L., Park, S., Dikau, R., and Vlek, P. (2005). Analysis of factors determining sediment yield variability in the highlands of Northern Ethiopia. Journal of Geomorphology, 76. 76-91.

18. Tsegaye, E. (2006). Regionalization of potential Evapotranspiration prediction for Blue Nile ( Abbay) river basin, Ethiopia.

19. USDA-SCS. (1972). US Department of Agriculture-Soil Conservation Service, National Engineering Handbook, Section IV, hydrology. 4 - 102.

20. Van Griensven, A., Meixner, T., Grunwald, S., T, B., Diluzio, M., and R, S. (2006). A global Sensitivity analysis tool for the parameters of multi-variable catchment models. J Hydrol: 324 (1 -4), 10 - 23.

21. Zemenfes, T. (1995). The Polotical economy of land degradation in Ethiopia. Northeast African Studies 2. 71 - 98. 
